\title{
Monosemptomatik Enürezis Noktürnalı Çocuklarda Hiperkalsiüri
} Hypercalciuria in Children with Monosymptomatic Nocturnal Enuresis

\author{
Mahmut Çivilibal, Ömer Sarılar*, Mehmet Toptaş** \\ Haseki Eğitim ve Araştırma Hastanesi, Çocuk Nefrolojisi Kliniği, istanbul, Türkiye \\ *Haseki Eğitim ve Araştırma Hastanesi, Üroloji Kliniği, istanbul, Türkiye \\ **Haseki Eğitim ve Araştırma Hastanesi, Anestezi ve Reanimasyon Kliniği, istanbul, Türkiye
}

\section{Özet}

Amaç: Enürezis noktürna çocukluk çağında yaygın bir problemdir. $\mathrm{Bu}$ çalışmada, monosemptomatik enürezis noktürnalı (MEN) çocuklarda idrar kalsiyum atılımın rolünü değerlendirmeyi amaçladık.

Yöntemler: Çalışmaya 60 MEN tanılı çocuk ve 30 sağlıklı kontrol alındı. Rutin testlere ilaveten, idrar dansitesi ve idrar kalsiyum ölçümleri yapıldı. İdrar kalsiyum atıımının $4 \mathrm{mg} / \mathrm{kg} / \mathrm{gün}$ veya idrar kalsiyum/kreatinin oranının 0.21 'den büyük olması hiperkalsiüri olarak tanımlandı.

Bulgular: Enürezis grubunda idrar kalsiyum atılımı kontrol grubuna göre anlamlı düzeyde yüksek bulundu ve enürezisli çocuklarda hipekalsiüri sıklığı \%25 idi.

Sonuç: Sonuç olarak, çalışmamız göstermiştir ki, hiperkalsiüri enürezis noktürnanın önemli bir bulgusudur. Fakat, bu ilişki başka çalışmalarla desteklenmelidir. (Haseki Tıp Bülteni 2014; 52: 39-42)

Anahtar Sözcükler: Çocuklar, hiperkalsiüri, enürezis noktürna

\begin{abstract}
Aim: Nocturnal enuresis is a common problem in childhood. We aimed to evaluate the role of urinary calcium excretion in children with monosymptomatic nocturnal enuresis (MNE).

Methods: This study included 60 children with MNE and 30 healthy controls. In addition to routine tests, urine density and urinary calcium levels were measured. Hypercalciuria was defined as the excess urinary calcium excretion $\geq 4 \mathrm{mg} / \mathrm{kg} /$ day or urinary calcium/creatinine ratio $\geq 0.21$.

Results: Urinary calcium excretion was significantly higher in the enuresis group compared with the control group and the prevalence of hypercalciuria was $25 \%$ in children with enuresis. In conclusion, our study showed that hypercalciuria is an important finding of nocturnal enuresis.

Conclusion: However, further studies are needed to clarify this relationship. (The Medical Bulletin of Haseki 2014; 52: 39-42)
\end{abstract}

Key words: Children, hypercalciuria, nocturnal enuresis

\section{Giriş}

Doğuştan ya da edinilmiş santral sinir sistemi bozukluğu olmayan 5 yaşın üzerindeki çocuklarda istemsiz olarak uykuda gece altını ıslatma enürezis noktürna olarak tanımlanır. Monosemptomatik enürezis noktürna (MEN) ve polisemptomatik (komplike) enürezis noktürna olarak iki alt grupta incelenir. MEN'de uykuda yatağı ıslatma dışında gün içinde herhangi bir belirti yoktur (1).
MEN etiyolojisinde bir ya da birden çok faktör rol oynayabilir. Genetik faktörler, uyanma bozuklukları, hormonal faktörler ve mesane ile ilişkili faktörler enürezise neden olabilir. Son yıllarda hiperkalsiürinin enürezis patogenezinde önemli olduğu iddia edilmiştir (2-5). Bu çalışmada MEN'li çocuklarda idrarla kalsiyum atııımı ve bununla ilişkili faktörlerin belirlenmesi amaçlandı. 


\section{Yöntemler}

Çalışma, Haseki Eğitim ve Araş̧ırma Hastanesi Çocuk Nefrolojisi Ünitesi ve Üroloji Kliniği'nde MEN tanısı konulan 60 hasta ile benzer yaş ve cinsiyetteki 30 sağlıklı çocukta yapıldı. MEN tanısının konulmasında "Rushton ölçütleri" esas alındı (6). Bu ölçütlere göre primer başlangıçlı, idrar akım paterni normal, diürnal semptomları olmayan, rutin idrar tetkikleri ve sedimenti normal, idrar kültürleri steril ve nörolojik muayenesi normal olan enürezis noktürnalılar MEN olarak kabul edilir.

Hasta ve kontrol grubunun ayrıntılı öyküleri alındı ve fizik muayeneleri yapıldı. Çocukların ağırlıkları $100 \mathrm{~g}$ hassasiyetli dijital tartı ve boyları stadiometre ile ayakta ölçüldü. Kan basıncı ölçümleri 15 dakika istirahat sonrası sağ koldan ve koluna uygun manşonla, oturur pozisyonda 3 kez ölçüldü ve ortalaması alındı. Rutin kan tetkikleri hazır ticari kitler yardımı ve standart yöntemlerle ölçüldü. İdrarda kalsiyum ölçümü ise Arsenazo metodu ile Abbott Architect C 16000 otoanalizoründe yapıldı.

Çalışma öncesinde Yerel Etik Kurul'dan onay alındı. Katılan çocukların ebeveynlerinden imzalı gönüllülük belgesi alındıktan sonra, Helsinki Bildirgesi'nde önerilen iyi klinik uygulaması kılavuzuna uyularak çalışma gerçekleştirildi.

\section{İstatistiksel Analizler}

Bu çalışmada normal dağılıma uygunluk testi Kolmogorov-Smirnov testi ile yapıldı. Elde edilen veriler ortalama, standart sapma ve yüzde olarak ifade edildi. ikili karşılaştırmalarda Mann-Whitney $U$ testi ve ki-kare testleri kullanıldı. Parametreler arasındaki korelasyonu belirlemede, numerik verilerin karşılaştııımasında Pearson testi ve kategorik verilerin karşılaştırılmasında Spearman testi kullanıldı. Bu yöntemle anlamlı ilişki saptanan parametrelere çoklu lineer lojistik regresyon analizi ugulanarak, bağımsız prediktörler belirlendi. Tüm istatistiksel analizler "SPSS (Statistical Package for Social Sciences Inc; Chicago, IL, USA) for Windows versiyon 16.0 paket program ile yapıldı. $P<0.05$ olarak belirlenen değerler istatistiksel olarak anlamlı kabul edildi.

\section{Bulgular}

Çalışma 60 monosemptomatik enürezis noktürnalı hasta (30'u erkek) ve 30 sağlıklı çocukta (15'i erkek) gerçekleştirildi. Hasta ve kontrol grubunun demografik özellikleri, muayene bulguları ve serum glukoz, üre, kreatinin, sodyum, potasyum, kalsiyum, fosfor ve hemoglobin düzeyleri benzerdi (Tablo 1).

Gece altını ıslatmayan çocuklarla karşılaştııılığında, enürezisli çocukların idrar dansitesinin düşük, spot idrarda $\mathrm{Ca} / \mathrm{Cr}$ oranının ve 24 saatlik idrarla kalsiyum atılımının anlamlı düzeyde yüksek olduğu saptandı. Ayrıca, enüretik olmayan yalnızca bir çocukta hiperkalsiüri saptanırken, enüretiklerin \%25'inde hiperkalsiüri olduğu belirlendi (Tablo 1).

Ebeveynlere uygulanan anket sonucunda; sağlıklı çocukların 25'inin (\%83) normal veya çabuk uyandırılabilen çocuklar, geri kalanının (\%15) zor uyandırılabilen çocuklar olduğu saptandı. Enürezisli grupta ise çocukların 37'si (\%62) zor uyandırılabilen çocuklardı. Sonuçta iki grup arasında uykudan uyandırılabilme konusunda istatiksel olarak ileri düzeyde anlamlı farklılık vardı $(p<0.001)$.

Idrarla kalsiyum atılımları cinsiyet açısından değerlendirildiğinde, enüretik erkek çocukların idrar kalsiyum düzeyleri kızlarınkine göre yüksek olmakla birlikte (sırasıyla, $3.14 \pm 3.06$ ve $1.90 \pm 1.77 \mathrm{mg} / \mathrm{kg} / \mathrm{gün}$ ) aralarında istatistiksel olarak fark yoktu $(p=0.062)$. Kontrol grubunda da erkek ve kızların idrar kalsiyum düzeyleri (sırasıyla, $1.72 \pm 2.17$ ve $1.45 \pm 1.79 \mathrm{mg} / \mathrm{kg} / \mathrm{gün}$ ) benzerdi $(p=0.45)$.

Enüretik hastalarda idrar kalsiyum atılımı düzeyi ile yaş, cinsiyet ve enürezisli kardeş varlığı arasında doğrusal ilişki saptandı (Tablo 2). Lojistik regresyon analizinde, hiperkalsiüri üzerine etkili tek bağımsız göstergenin erkek cinsiyeti olduğu belirlendi $(\beta=0.386 p=0.009)$.

\section{Tartışma}

Enürezis noktürna çocukluk çağının en sık karşılaşılan üriner sistem sorunlarından birisidir. Sıklığı toplumlara göre değişmekle birlikte, genel olarak 5 yaş civarında \%15-\%20, 10 yaşında \%7, 12 yaşında \%3 ve 15 yaşından sonra \%1 olduğu kabul edilir $(7,8)$. Enürezis noktürna fizyopatolojisinde klasik olarak üç faktör rol oynar: Uyanma bozukluğu, gece mesane kapasitesinin azalması ve gece idrar miktarının artması (noktürnal poliüri).

Enürezis ile uyku arasında ilişki uzun zamandan beri bilinen ve üzerinde çalışılan bir konudur. Enürezisli çocukların aileleri de çoğunlukla çocuklarının uykularının çok ağır olduğunu ifade ederler ve çocuğun uykuda idrar kaçırmasını buna bağlarlar. Bu gözlemsel bulguların yanı sıra objektif ölçütlere dayalı çalışmalar da vardır. Uykuda EEG çekilmesi destekli yapılan çalışmalarda, enürezisin uykunun herhangi bir döneminde olabileceği gösterilmiştir (9). Wille ve ark. (10) da enüretik olan ve olmayan çocukların ebeveynlerinden bir ucunda "iğne düşse uyanır", diğer ucunda "top patlasa uyanmaz" ifadelerinin yer aldığı bir ölçek ile çocuklarının uykularını değerlendirmelerini istemişlerdir. Çalışma sonucunda enürezis noktürnalı olguların \%71'inin "top patlasa uyanmaz" şeklinde çok zor uyandırılabildiğini, enüretik olmayanlarda ise bu oranın \%7 olduğu saptanmıştır.

Çalışmamızda biz de, anne ve babalara benzer şekilde üç seçenek vererek (çabuk uyandırılabilen, normal ve zor uyandırılabilen) çocuklarının uyku durumlarını sorguladık. MEN'li çocuklarımızın \%62'sinin, enüretik olmayanların ise 
Tablo 1. Enürezis nokturnalı ve altını ıslatmayan çocukların özellikleri

\begin{tabular}{|c|c|c|c|}
\hline & $\begin{array}{l}\text { Enürezis grubu } \\
\qquad(n=60)\end{array}$ & $\begin{array}{l}\text { Kontrol grubu } \\
(n=30)\end{array}$ & $\mathbf{p}$ \\
\hline Yaş (yıl) & $8.99 \pm 2.42$ & $9.13 \pm 2.02$ & $A D$ \\
\hline Cinsiyet (E/K) & $30 / 30$ & $15 / 15$ & $A D$ \\
\hline Enürezisli kardeş sayısı (ortanca) & 2 & 2 & $A D$ \\
\hline Tuvalet eğitimi yaşı (ay) & $22.4 \pm 6.1$ & $21.5 \pm 2.7$ & $A D$ \\
\hline Kilo (kg) & $28.0 \pm 7.5$ & $30.5 \pm 7.6$ & $A D$ \\
\hline Boy $(\mathrm{cm})$ & $129.2 \pm 13.0$ & $131.7 \pm 11.7$ & $A D$ \\
\hline Vücut kitle indeksi $\left(\mathrm{kg} / \mathrm{m}^{2}\right)$ & $16.5 \pm 2.1$ & $17.3 \pm 1.9$ & $A D$ \\
\hline Sistolik kan basıncı (mmHg) & $103.5 \pm 10.5$ & $102.0 \pm 8.3$ & $A D$ \\
\hline Diyastolik kan basıncı (mmHg) & $67.2 \pm 6.7$ & $66.2 \pm 5.9$ & $A D$ \\
\hline Glukoz (mg/dl) & $86.9 \pm 8.2$ & $90.3 \pm 7.4$ & $A D$ \\
\hline Üre (mg/dl) & $24.3 \pm 6.1$ & $21.7 \pm 5.5$ & $A D$ \\
\hline Kreatinin (mg/dl) & $0.51 \pm 0.08$ & $0.53 \pm 0.70$ & $A D$ \\
\hline Sodyum (mEq/L) & $139.1 \pm 1.9$ & $138.1 \pm 1.9$ & $A D$ \\
\hline Potasyum (mEq/l) & $4.21 \pm 0.34$ & $4.09 \pm 0.38$ & $A D$ \\
\hline Kalsiyum (mg/dl) & $9.94 \pm 0.38$ & $9.90 \pm 0.34$ & $A D$ \\
\hline Fosfor (mg/dl) & $3.98 \pm 0.32$ & $3.76 \pm 0.29$ & $A D$ \\
\hline Hemoglobin $(g / d l)$ & $12.5 \pm 0.9$ & $12.3 \pm 0.9$ & $A D$ \\
\hline İdrar dansitesi & $1017.9 \pm 6.9$ & $1021.0 \pm 7.7$ & 0.041 \\
\hline İdrar pH & $5.68 \pm 0.52$ & $5.61 \pm 0.41$ & $A D$ \\
\hline İdrar kalsiyum atılımı (mg/kg/gün) & $2.94 \pm 1.42$ & $1.62 \pm 1.22$ & 0.041 \\
\hline İdrarda kalsiyum/kreatinin ( $\mathrm{mg} / \mathrm{mg})$ & $0.25 \pm 0.20$ & $0.15 \pm 0.14$ & 0.039 \\
\hline Hiperkalsiüri sıklığı, n(\%) & $15(25)$ & $1(3)$ & $<0.001$ \\
\hline
\end{tabular}

Tablo 2. Enürezis noktürnalı hastalarda idrar kalsiyum düzeyi üzerine etkili faktörler (spearman korelasyon analizi, sadece anlamlı olanlar verilmiştir)

\begin{tabular}{|l|c|c|}
\hline & $\mathbf{r}$ & $\mathbf{p}$ \\
\hline Yaş & 0.212 & 0.032 \\
\hline Erkek cinsiyeti & 0.483 & 0.006 \\
\hline Enürezisli kardeş varlığı & 0.254 & 0.021 \\
\hline
\end{tabular}

\%15'inin zor uyandırılabilen çocuklar olduğunu saptadık. Bu bulgumuz uyku durumu ile enürezis arasında anlaml bir ilişki olduğunun kanıtıdır.

Bu çalışmanın ana konusu, enürezis noktürnalı çocuklarda idrarla kalsiyum atıımının ve bununla ilişkili faktörlerin belirlenmesi idi. Normal popülasyonda hiperkalsiüri sıklığının \%3-\%7 arasında olduğu bildirilmiştir $(11,12)$. Çalışmamızda gece altını ıslatmayan sağlıklı çocuklarımızdan sadece birisinde (\%3) hiperkalsiüri belirledik.

Hiperkalsiürisi olan kişilerde yan ağrısı, karın ağrısı, böbrek taşı, idrar yolu enfeksiyonu, hematüri ve işeme disfonksiyonu gibi bir dizi klinik bulgu olabilir. Büyük bir bölümü ise tamamen asemptomatik olabilir ve tesadüfen belirlenirler. Hiperkalsiürinin hematüri ve üriner sistem taş hastalığı ile ilişkisi net olarak biliniyor olmasına rağmen, enürezis üzerindeki etkisi tam olarak açıklanamamıştır. Bu konuyu ilk olarak Pace ve ark. (2) araştırmış ve enüretik çocukların bir bölümünde hiperkalsiüri olduğunu saptamışlardır. Ayrıca, bu çocuklarda düşük kalsiyum ve sodyum diyeti ile klinik düzelme olduğunu ortaya koymuşlardır. Sonrasında yapılan çalışmaların bazıları bu fikri desteklerken, bazıları ise enürezis ile hiperkalsiüri arasında ilişki olmadığını ileri sürmektedir (2,5,13-16). Bu çelişki etnik, çoğrafik ve beslenme alışkanlığı farklııklarından kaynaklanabilir. Fakat, bu farklı sonuçların elde edilmesindeki en önemli etkenin, çalışmaların çoğunluğunda hiperkalsiüri tayini için spot idrarda kalsiyum/kreatinin oranının belirlenmiş olmasıdır. Çalışmamızda hiperkalsiüri tanımlamasında altın standart olarak kabul edilen 24 saatlik idrarda kalsiyum tayini yapıldı. Enürezis noktürnalı çocukların idrar kalsiyum düzeyi ortalaması, enüretik olmayanlarınkine göre anlamlı düzeyde yüksek bulundu ve enüretiklerin $\% 25^{\prime}$ inde hiperkalsiüri olduğu belirlendi. 
Çalışmamızda hiperkalsiüri alt tipinin belirlenmesi için özel bir çaba harcanmadı. Klasik olarak hiperkalsiüri, absorbtif, rezorbtif ve renal olarak üç alt grupta incelenir $(2,11)$. Hiperkalisürili hastalarımızın serum kalsiyum, fosfor, sodyum, potasyum ve parathormon düzeylerinin normal olması nedeniyle absorbtif ve rezorbtif hiperkalsiüri tipleri dışlandı.

Idrarla kalsiyum atılımları cinsiyet açısından değerlendirildiğinde, enüretik erkek çocuklarımızın idrar kalsiyum düzeyleri kızlarınkine göre istatistiksel anlamlılığa ulaşmayan düzeyde yüksekti. Ayrıca, hastalarımızda hiperkalsiüri ile yaş, erkek cinsiyeti ve enürezisli kardeş varlığı arasında saptanan doğrusal ilişkiye, lojistik regresyon analizi uygulandığında, hiperkalsiüri üzerine etkili tek bağımsız göstergenin erkek cinsiyeti olduğu belirlendi. Bir başka anlatımla, enürezis noktürnalı çocuklarda hiperkalsiüri yaygın görülen bir bulgudur ve özellikle de erkek çocuklarında daha fazla önemsenmesi gereken bir durumdur. Literatürle desteklenemeyen bu bulgunun önemli olduğunu ve üzerinde durulması gereken bir sonuç olduğunu söyleyebiliriz.

Sonuç olarak, çalışmamız enürezis noktürnalı çocukların önemli bir bölümünün hiperkalsiürik olduğu görüşünü desteklemektedir. Bu çocuklarda hiperkalsiürinin belirlenmesi, önlenmesi veya gerektiğinde tedavi edilmesinin, enürezis tedavisinde etkin olacağını düşünüyoruz. Daha geniş kapsamlı çalışmalar ve meta-analizlerle bu konunun daha ayrıntılı incelenmesini öneririz.

\section{Kaynaklar}

1. Neveus T, von Gontard A, Hoebeke P, et al. The standardization of terminology of lower urinary tract function in children and adolescents: report from the Standardisation Committee of the International Children's Continence Society. J Urol 2006;176:314-24.

2. Pace $G$, Aceto $G$, Cormio L, et al. Nocturnal enuresis can be caused by absorptive hypercalciuria. Scand J Urol Nephrol 1999;33:111-4.
3. Deen PM, Daht N, Caplan MJ. The aquaporin2 water channel in autosomal dominant primary nocturnal enuresis. J Urol 2002;167:1447-50.

4. Nevéus T, Hansell P, Stenberg A. Vasopressin and hypercalciuria in enuresis: a reappraisal. BJU Int 2002;90:725-9.

5. Valenti G, Laera A, Pace $G$, et al. Urinary aquaporin 2 and calciuria correlate with the severity of enuresis in children. J Am Soc Nephrol 2000;11:1873-81.

6. Rushton HG. Nocturnal enuresis epidemiology evalution and currently avaible treatment options. J Pediatr 1989;114:691-6.

7. Akis N, Irgil E. Enuresis and Effective Factors. Scand J Urol Nephrol 2002;36:1999-2003.

8. Chiozza ML, Bernardinelli L. An Italian epidemiological multicentre study of nocturnal enuresis. BJU 1998;3:86-9.

9. Norgaard JP. Pathophysiology of nocturnal enuresis. Scand J Urol Nephrol Suppl. 1991;140:1-35.

10. Wille S. Comparison of desmopressin and enuresis alarm for nocturnal enuresis. Arch Dis Child 1986;61:30-3.

11. Penido MG, Diniz JS, Moreira ML, et al. Idiopathic hypercalciuria presentation of 471 cases. J Pediatr (Rio J) 2001;77:101-4.

12. Sargent JD, Stukel TA, Kresel J, Klein RZ. Normal values for random urinary calcium to creatinine ratios in infancy. J Pediatr 1993;123:393-7.

13. Mohammadjafari $H$, Kosaryan $M$, Karami $H$, Dabaghzadeh $A$. Response of Enuretic Children with and without Hypercalciuria to Nasal Desmopressin. Iran j Pediatr. 2009;19:5-10.

14. Valavi E, Ahmadzadeh A, Hooman N, Aminzadeh M. Clinical correlation between hypercalciuria and nocturnal enuresis. Saudi J Kidney Dis Transpl 2011;22:976-981.

15. Nikibakhsh A, Poostindooz H, Mahmoodzadeh H, Karamyyar M, Ghareaghaji RR, Sepehrvand N. Is there any correlation between hypercalciuria and nocturnal enuresis? Indian J Nephrol 2012;22:88-93.

16. Kalman S, Sakallığlu O, Kesik V, Gök F. Primer Nokturnal Enürezisli Çocuklarda Renal Tubuler Fonksiyonlar. Haseki Tıp Bülteni 2012;50:10-3. 